\title{
MODERNÍ METODY PRO OPTIMALIZACI NÁKLADU゚ DOPRAVNÍCH STAVEB
}

\section{MODERN METHODS FOR COST OPTIMIZATION IN TRANSPORT CONSTRUCTIONS}

\author{
Miroslav Bartoš ${ }^{1}$, Karol Urban $^{2}$, Stanislav Vitásek ${ }^{3}$ \\ ${ }^{1}$ Brno University of Technology, Faculty of Civil Engineering, Veveri 331/95, 60200 Brno, Czech \\ Republic, bartosm5@study.fce.vutbr.cz \\ ${ }^{2}$ Technical University of Kosice, Faculty of Civil Engineering, Vysokoskolska 4, 04200 Kosice, Slovak \\ Republic, karol.urban@tuke.sk \\ ${ }^{3}$ Skanska, Krizikova 682/34a, 18600 Prague, Czech Republic
}

\begin{abstract}
Abstrakt - CZ
Článek se zabývá moderními nástroji, které umožňují snížit náklady v průběhu životního cyklu dopravních staveb. Počínající návrhem, výstavbou, údržbou a provozem díla po celou dobu její životnosti. Nové metody správy a organizace ve stavebnictví přinášejí transparentnější a reálnější informace o nákladech, které do daného objektu plynou. Jedním z možných nástrojů je software na bázi CAFM a CIFM prostředí. Použití těchto nástrojů je převážně v provozní fázi stavebního díla. Komplexní řešení přináší informační modelování (BIM), které je schopno pojmout náklady objektu od plánování výstavby přes její správu až po její zánik.
\end{abstract}

\section{Klíčová slova - CZ}

BIM, náklady, dopravní stavby.

\section{Abstract - EN}

The paper deals with modern tools, which reduce costs during the traffic infrastructure life cycle. From design, construction, maintenance and operation of the construction work to the end of useful life. New management and organization methods in the construction industry provide more transparent and more realistic information about the cost of the building. One of the possible tools is software based on CAFM and CIFM environments. The use of these tools is predominantly in the operational phase of the construction work. The complex solution brings building information modeling (BIM), which includes the cost of an object from design to disposal.

\section{Keywords - EN}

BIM, cost, transport constructions.

\section{JEL Classification}

R4 Transportation Economics.

DOI: https://doi.org/10.14311/bit.2016.02.04

Editorial information: journal Business \& IT, ISSN 2570-7434, CreativeCommons license (c) (i) published by CTU in Prague, 2016, http://bit.fsv.cvut.cz/ 


\section{Úvod}

V současné době je v naší společnosti často diskutována situace okolo dopravních staveb. Panuje značné nespokojení s kvalitou a náklady na vybudování nových úseků včetně rekonstrukcí stávající infrastruktury. Článek se zabývá vhodnou implementací nástrojů souvisejících s facility managementem (FM) pro dopravní infrastrukturu, jenž má za cíl optimalizaci nákladů $v$ průběhu celé životnosti stavebního díla. [1]

Optimalizace nákladů v dopravní infrastruktuře je naprosto nutná vzhledem $\mathrm{k}$ situaci, kdy do výstavby a rekonstrukcí jsou vynakládány každoročně miliardy Kč. O rozdělování prostředků určených pro dopravní stavitelství v ČR rozhoduje Státní fond dopravní infrastruktury (SFDI). Tento fond přerozděluje finanční prostředky hlavně mezi Ředitelství silnic a dálnic ČR (ŘSD) a Správu železniční dopravní cesty (SŽDC). [2]

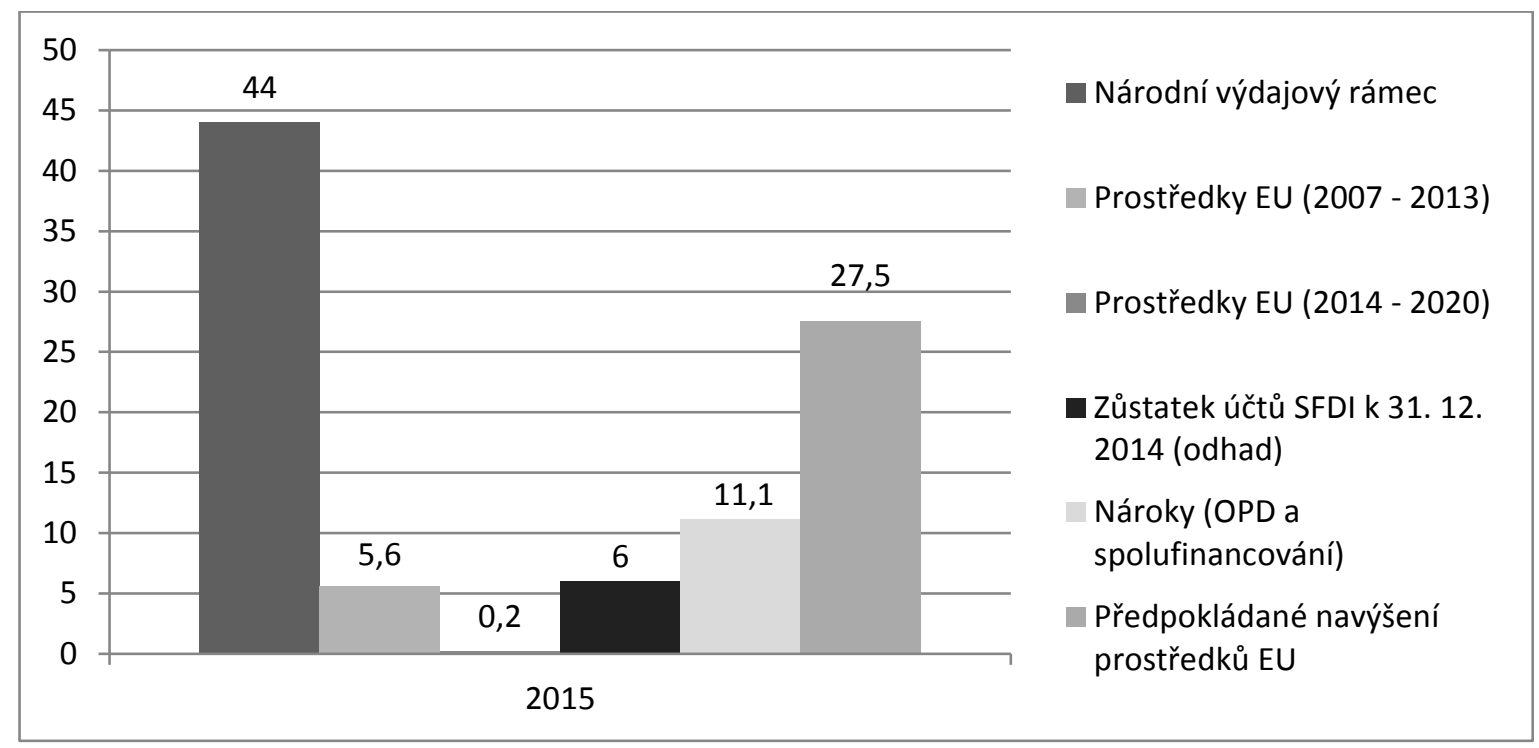

Obrázek 1: Zdroje financí SFDI pro rok 2015 [3]

Obrázek 1 zobrazuje složení zdrojů v miliardách rozpočtu SFDI pro rok 2015, který operuje celkem se sumou 94,4 miliardy Kč.

Samotné použití služeb FM u dopravních staveb není v ČR zcela obvyklé. Avšak stavební společnosti, které tyto stavby staví, se bez služeb FM neobejdou. FM se zabývá převážně efektivností vynaložených nákladů za správu stavebního objektu. Tato potřeba optimalizovat náklady za provoz je s rostoucími cenami za energie a neustále prohlubujícímu se tlaku na hledání úspor, stále žádanější. U dopravních staveb na rozdíl od klasických pozemních, je z hlediska LCC (life cycle cost) největší spotřeba nákladů v investiční fázi životního cyklu. [4] Výši nákladů v investiční etapě, Ize nejvíce ovlivnit právě v jejím samotném návrhu.

Kromě správy objektů je dalším cílem FM zajistit určité služby, tak aby se podnik mohl koncentrovat na hlavní činnost svého podnikatelského záměru. Tyto podpůrné procesy mají vést také $k$ úspoře vynaložených nákladů podniku. Optimalizace nákladů za provoz a podpůrných činností vede ke snížení režijních nákladů, které se promítají do nižších cen nabízených služeb, což přináší konkurenční výhodu. [5] 


\section{FM v životním cyklu stavebního díla}

Různé aktivity v portfoliu FM se dají použít v každé fázi životního cyklu staveb. $V$ různých etapách nastupují charakteristické druhy těchto služeb. Pro efektivní výsledky je vhodné, aby se touto agendou zabýval facility manažer. Facility manažer je osoba, která zajišt́uje a kontroluje veškeré procesy FM v podniku. [6]

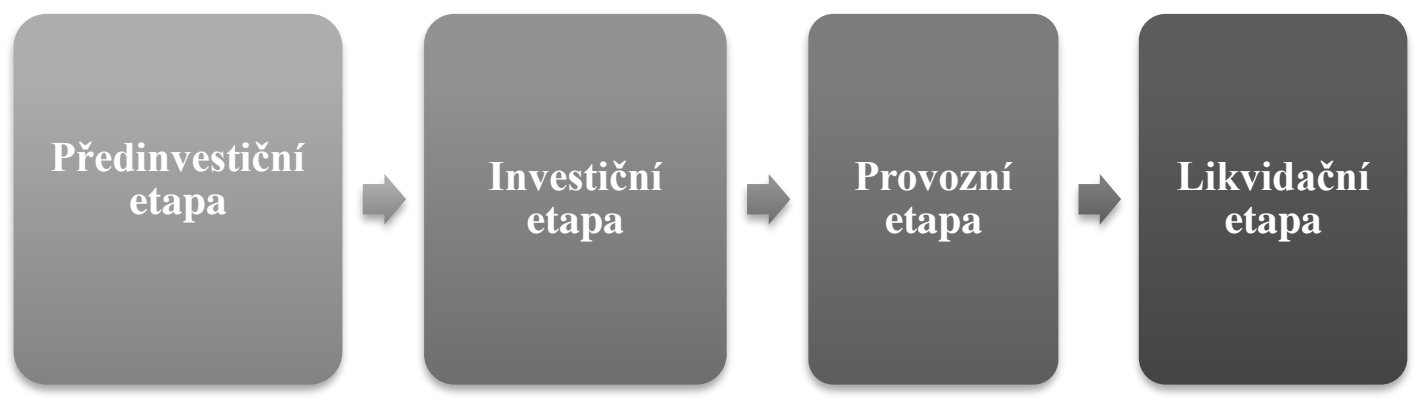

Obrázek 2: Životní cyklus stavebního díla [7]

\section{Předinvestiční fáze}

Jak už je zmíněno v úvodu, náklady na samotnou výstavbu nebo na budoucí provoz, lze nejlépe ovlivnit $v$ předinvestiční fázi projektu. Úloha facility manažera je $v$ poradenství založeném na zkušenostech a rozhledu pro užití různých technologií a variant materiálového složení v konstrukcích. Změny navrhnuté facility manažerem se $v$ této etapě promítají do projektové dokumentace a mají za následek dosažení optimalizace nákladů v provozní etapě stavebního díla. [8]

Služby FM pro předinvestiční fázi vhodné pro použití v dopravním stavitelství:

- poradenství v použití převážně technologických zařízení a stavebních materiálů,

- vypracování studie proveditelnosti,

- zajištění spolupráce na ose investor- projektant- generální dodavatel stavebního díla.

\section{Investiční fáze}

V investiční fázi dochází $k$ výstavbě samotného díla a i zde nachází své uplatnění FM. Jedná se zvláště o zajištění různých služeb v průběhu výstavby. Zejména o dokumentování rozdílů oproti původní dokumentaci se zaměřením na změny technologických zařízeních. [9]

Služby FM pro investiční fázi vhodné pro použití v dopravním stavitelství:

- účast na kontrolních dnech výstavby,

- zajištění ostrahy staveniště,

- úklid staveniště a okolí,

- kontroly dodávek a montáží technologických zařizení,

- účast při individuálních a komplexních zkouškách,

- různé poradenské služby ohledně BOZP, PO a reklamací.

\section{Provozní fáze}

Provozní fáze životního cyklu je obvykle nejdelším obdobím. U samotných dopravních staveb je využití FM velice omezené. Spíš se jedná o klasické portfolio služeb pro samotný chod stavební společností, které mají na starosti údržbu či modernizaci/rekonstrukci dopravního úseku. [10]

Ideální kandidáty na využití správy pomocí FM služeb představují inženýrské stavby, které se v dopravním stavitelství běžně používají, jako například mosty a tunely. [11] 
Služby FM pro investiční fázi vhodné pro použití v dopravním stavitelství:

- provozní správa objektu,

- údržba stavební části stavby,

- servis a revize technologických zařízení.

\section{Softwarová podpora pro FM}

Softwarová podpora FM tvoří nepostradatelný nástroj, vzhledem ke zpracování velkého množství dat o objektu. Hlavně v oblastech správy technologií, údržbě, energií a materiálových složení konstrukcí. V současnosti se obvykle používají softwary vyvinuté speciálně pro potřeby FM. Tyto softwary nesou označení CAFM (Computer Aided Facility Management) a CIFM (Computer Integrated Facility Management). Princip je založen na propojení grafických softwarů na bázi CAD (Computer aided design) a databázových programů. [12] V poslední době vstupují do popředí projekty založené na BIM (Building Information Modeling) modelu, které predstavují budoucnost nejen pro softwarovou podporu FM. Použití těchto softwarů vede k efektivní správě objektů a tudiž ke snížení provozních nákladů.

Nevýhodou těchto softwarových podpor je jejich cena. Některé podniky nehodlají či si nemůžou dovolit vynaložit nemalé finanční prostředky, které slouží převážně ke správě a údržbě objektů.

\section{CAFM a CIFM}

CAFM a CIFM představují informační systémy, který tvoří moderní nástroje pro správu objektu. Softwary založené na CAFM a CIFM umožňují ř́dit veškeré oblasti FM včetně samotného managementu podpůrných procesů. Tyto druhy softwaru používá většina společností zabývající se FM na českém trhu. [13]

Výhody CAFM a CIFM systémů:

- zajištují souhrnný obsah o stavu objektu a outsourcingových službách v jednom softwaru,

- přehledné uživatelské prostředí,

- možnost velkého množství grafických výstupů,

- obsahují velké množství různých modulů pro zajištění služeb FM,

- synchronizování se softwary určených k účetnictví a ekonomice podniku.

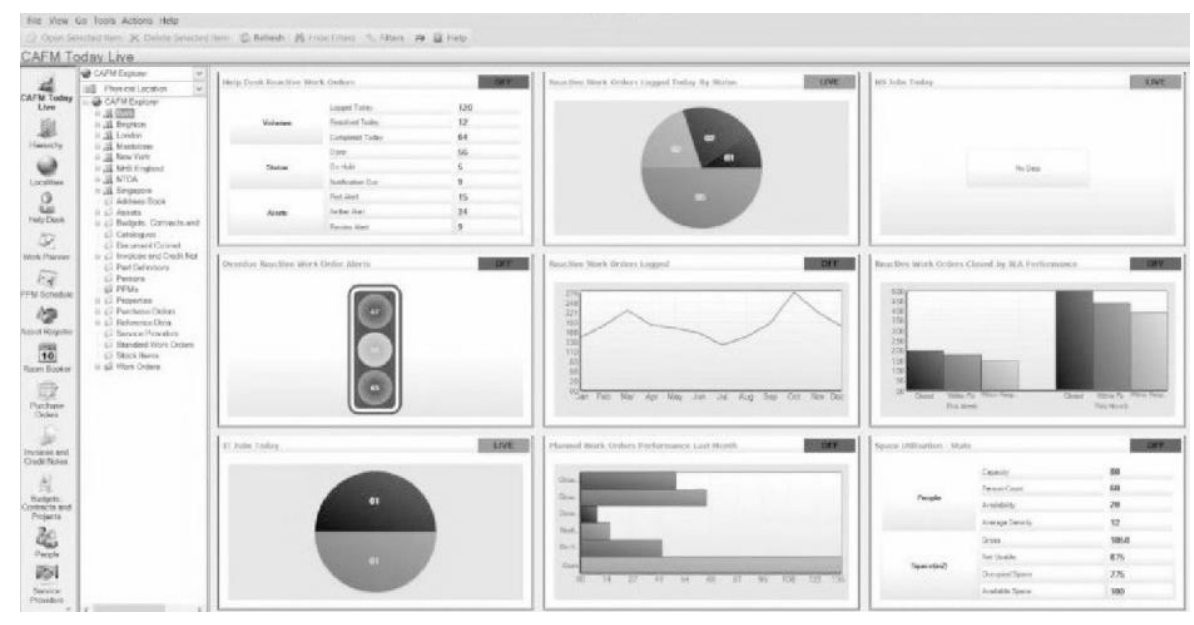

Obrázek 3: Životní cyklus stavebního díla [software CAFM Explorer]

Na obrázku 3 je zobrazena ukázka ze softwaru CAFM Explorer. Tento snímek přináší názorný příklad užití tohoto softwaru. Nese informace o funkci místnosti, technické údaje materiálových konstrukcí 
(podlahy, stropy, zdi), data o pracovnících, kteří místnost spravují včetně soupisu, revizí, výměn a oprav technologických zařizení.

\section{BIM model}

BIM model představuje moderní nástroj určený pro všechny obory stavitelství. Tento model postupuje napříc celého životního cyklu stavebního díla a $v$ ideálním případě obsahuje veškeré informace o prvcích, z kterých je složen. Vkládání a konečný obsah informací v BIM modelu je závislé na př́stupu a odbornosti každého vkladatele. Optimální spolupráce na tvoření BIM modelu je na ose architekt, projektant, generální dodavatel stavebního díla, facility manažer a investor. Pokud všechny tyto profese spolupracují a přidávají informace do vytvářeného modelu, stává se z něj nejen z pohledu FM nepostradatelný nástroj pro moderní stavitelství. [14] Výsledný model usnadňuje představu o díle, samotnou výstavbu a budoucí správu objektu. BIM aktuálně nastupuje při vytváření nákladově náročných projektů jako právě výstavby dopravní infrastruktury převážně v západních zemích $v$ čele s Velkou Británií.

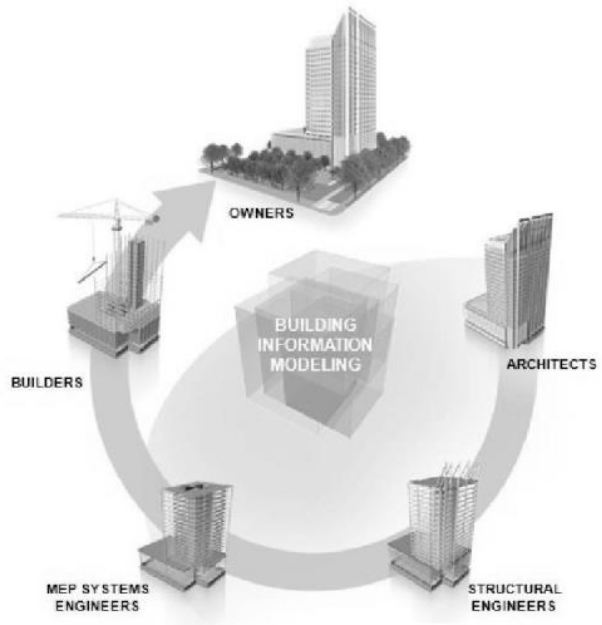

\section{Obrázek 4: Provázanost profesí BIM modelu [15]}

Na obrázku 4 se znázorňuje schéma BIM modelu od samotného návrhu až po předání investorovi, tedy předinvestiční a investiční fázi životního cyklu stavebního díla. Díky této provázanosti mají uživatelé, správci, investoři dostupné veškeré informace o budově na jednom místě a to bez nutné implementace dalších softwarů. [16] Na českém trhu existuje nemalá skupina softwarů, které umožňují vytvářet model BIM. Jedná se hlavně o společnosti Autodesk (produkt Revit) a Graphisoft (produkt Archicad).

BIM model umožňuje vygenerování výkazů výměr, který usnadňuje a zpřesňuje práci stavebních rozpočtářu při vytváření rozpočtů. Nadnárodní stavební podniky působící v ČR, aktuálně vyjednávají ve spolupráci se společnostmi Autodesk, Inc. a ÚRS, a.s. o modifikaci generovaných výkazů pro české prostředí. $V$ dnešní podobě už tyto softwary sestavují výkazy, ale ty nejsou vždy zcela přesné a přehledné. Ideální případ, kdyby samotný grafický software vyprodukoval položkový rozpočet ve struktuře podle Tř́dníku stavebních konstrukcí a prací (TSKP) je neproveditelný. Tento stav by vyžadoval znalosti návrhu a prostředí grafických softwarů, ale zároveň dovednost tvorby položkových rozpočtů. Plánovaná modifikace generovaných výkazů se zaměřuje spíše na zpřesnění výměr a pomocné třídění položek. Tabulka 1 je príkladem optimálních výstupů získaných ze softwaru založeném na BIM modelu. Trídění položek se provádí pomocí dvou až šestimístného kódu závislým na podrobnosti nástroje prvku. Toto třídění je vyobrazeno ve sloupci TSKP. I takovéto částečné zatřídění pomůže rozpočtářovi k ujasnění detailů o prvku a vede ke správnému zařazení položky v rozpočtovém softwaru. 
Tabulka 1: Optimální výstup z modelu BIM [17]

\begin{tabular}{|l|l|l|r|r|r|}
\hline Podlaží & Typ prvku & Materiál & Plocha povrchu & Objem & TSKP \\
\hline $1 . \mathrm{NP}$ & Zed' & Zdivo - lehčená tvárnice & 222,14 & 21,71 & 311272 \\
\hline 1. NP & Okno & Výplň pozadí & 4,00 & 1,80 & 766 \\
\hline 1. NP & Prvek & Beton vyztužený & 102,80 & 4,63 & 27 \\
\hline
\end{tabular}

I tento způsob optimálního výstupu vyžaduje, alespoň minimální znalosti problematiky tvorby položkových rozpočtů pomocí TSKP od projektantů či architektů. $V$ některých případech je nutné zatřídění od samotného autora projektové dokumentace, tak aby generovaný výstup byl co nejpřesnější.

Nevýhodou modelů BIM v ČR spočívá v malé informovanosti stavebních podniků o této metodě modelování stavebních děl a prípadné nemalé investici do softwaru. $V$ našich podmínkách s modelem na bázi BIMu pracují spíše architekti pro vytváření studií a vizualizací. S takto vytvořeným prvotním modelem už se pro podrobnější stupně projektové dokumentace dále obvykle nepokračuje. Rozvoji projektů založených na BIM modelu zatím nepřeje ani naše právní prostředí pro užití ve veřejných zakázkách.

\section{Optimalizace nákladů pomocí FM}

Vhodnou optimalizaci nákladů $v$ dopravním stavitelství pomocí FM vyplývající z prededchozích odstavců jsou:

- služby FM poskytované facility manažerem,

- aplikace modelu na bázi prostředí BIM,

- použití CAFM a CIFM softwarů.

Krom technického managementu převážně zaměřeného na použití technologického vybavení, je vhodné již ve fázi návrhu vybrat dodavatelskou firmu pro zajištění údržby a správy tohoto technologického vybavení. Tento krok obvykle přináší snižení budoucích provozních nákladů, z pohledu detailní znalosti objektu dodavatelskou firmou a zapracováních jejích praktických připomínek do realizace díla.

Budoucnost $v$ optimalizaci nákladů v dopravním i pozemním stavitelství představuje model BIM. Obrázek 5 srovnává efektivnost vynaložených nákladů $v$ čase na modelu tvořeném tradiční cestou a pomocí modelu BIM. Tradiční cestou je myšleno zajištění dokumentace pomocí klasických CAD systémů. $V$ př́padě BIM modelu dochází ke změnám a úpravám hlavně v předinvestiční fázi, oproti tradičnímu řešení, kdy jsou objevené chyby až v průběhu realizace. Zachycení nedostatků v raných fázích projektu je z jakéhokoliv pohledu žádoucí jev. Nejvíce nákladné a časově náročné jsou úpravy projektu při jeho samotné realizaci.

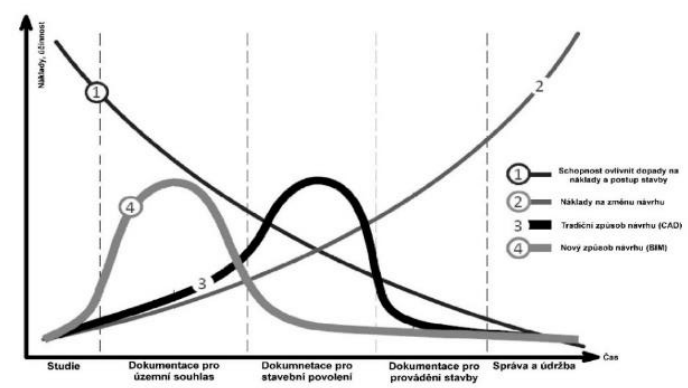

Obrázek 5: Optimalizace nákladů pomocí BIM modelu [18] 
Všechny navrhované změny v praxi záleží na rozhodnutí samotného investorova. Investoři v př́padě výstavby dopravní infrastruktury jsou převážně veřejné instituce, které provádějí výběr dodavatele podle zákona o veřejných zakázkách č. 137/2006 Sb. Bohužel tento zákon stále preferuje nejnižší pořizovací náklady nad LCC, a tudíž brání k optimalizování nákladů životního cyklu stavebního díla.

\section{Závěr}

Zahrnutí služeb FM ve větším měřítku v dopravní infrastruktuře by určitě vedlo k vhodné optimalizaci nákladů jak v samotné výstavbě, tak v provozu. Zapojení zejména facility manažera už v předinvestiční fázi je určitě více než žádoucí. Dalším nástrojem, který prospěje ke snížení pořizovacích a provozních nákladů je začlenění softwarových podpor. Nejvíce užitečné a efektivní se jeví softwary pro vytváření BIM modelu. Model BIM představuje ideální myšlenku pro komplexní správu celého projektu od fáze návrhu objektu až po její likvidaci. Bohužel se znalostí českého prostředí se obávám, že tento styl vedení projektu jako celku jak v soukromém, tak ve veřejném sektoru, se v blízkém horizontu nepovede bez legislativních změn plošně prosadit.

Legislativní změny jsou nutné zejména u zákona o veřejných zakázkách č. 137/2006 Sb. Současná politika nejnižších nabídkových cen znemožňuje užití nejmodernějších prostředků hlavně v souladu $s$ metodou LCC pro efektivní výstavbu a údržbu nejen u dopravních staveb. Př́hodnou změnou $\mathrm{k}$ optimalizaci nákladů je také modifikace či úplné opuštění od aktuální metody vyhodnocování ekonomické efektivnosti u silničních a dálničních staveb pomocí softwaru HDM-4, který používá ŘSD. Úskalí HDM-4 spočivá ve vysoké pravděpodobnosti kladného vyhodnocení ekonomické efektivnosti projektu výstavby. To je z mého pohledu kontraproduktivní s ohledem na objektivitu nutnosti výstavby nových úseků. Optimalizace opuštěním od této metodiky spočívá v ušetření prostředků za studie a realizace někdy nesmyslných úseků, například různých obchvatů měst a možností investování do skutečně nezbytných částí naší infrastruktury.

\section{Poděkování}

Tato práce vznikla za podpory grantu z Českého vysokého učení technického $v$ Praze, grant č. SGS16/026/OHK1/1T/11.

\section{Literatura}

[1] Hromada, E. Life Cycle Costing from the Investor's and Facility Manager's Point of View. In: Central Europe towards Sustainable Building 2016 - Innovations for Sustainable Future. Praha: GRADA PUBLISHING, 2016. pp. 1374-1380. 1st edition, Prague, June 2016, Complete edition - printed version + Flash disk with full paper version. ISBN 978-80-271-0248-8.

[2] Schneiderová Heralová, R. Possibility of Using Value Engineering in Highway Projects. In: Procedia Engineering. Amsterdam: Elsevier B.V., 2016. pp. 362-367. vol. 164. ISSN 1877-7058. https://doi.org/10.1016/j.proeng.2016.11.631

[3] State Transportation Infrastructure Fund. Budget 2015. Available online at: http://www.sfdi.cz/soubory/obrazky-clanky/dokumenty-2014/2014_rozpocet2015.pdf (accessed 20 Jan 2016).

[4] Hromada, E. Construction of Traffic Infrastructures: Causes of Low Effectiveness. Procedia Engineering. 2014, 2014(85), 251-259. ISSN 1877-7058. https://doi.org/10.1016/j.proeng.2014.10.550

[5] Macek, D.; Dobiáš, J. Life cycle costing of large-scale bridges used during the tender process subjected by design and build contracts. In: Central Europe towards Sustainable Building 2016 - Innovations for Sustainable Future. Praha: GRADA PUBLISHING, 2016. pp. 1418-1423. 1st edition, Prague, June 2016, Complete edition - printed version + Flash disk with full paper version. ISBN 978-80-271-0248-8. 
[6] Hromada, E.; Schneiderová Heralová, R.; Johnston, H.J. Cost Structure of the Highway Projects in the Czech Republic. Procedia Engineering. 2014, 2014(85), 222-230. ISSN 1877-7058.

https://doi.org/10.1016/j.proeng.2014.10.547

[7] Schneiderová Heralová, R. Life Cycle Cost optimization within decision making on alternative designs of public buildings. Procedia Engineering. 2014, 2014(85), 454-463. ISSN 1877-7058. https://doi.org/10.1016/j.proeng.2014.10.572

[8] Macek, D.; Snížek, V. Innovation in Bridge Life-cycle Cost Assessment. In: Procedia Engineering. Amsterdam: Elsevier B.V. pp. 441-446. vol. 196. ISSN 1877-7058. https://doi.org/10.1016/j.proeng.2017.07.222

[9] Matějka, P.; Berka, V. The Evaluation Methodology for Building Information Modeling in Construction Projects. In: Central Europe towards Sustainable Building 2016 - Innovations for Sustainable Future. Praha: GRADA PUBLISHING, 2016. pp. 845-852. 1st edition, Prague, June 2016, Complete edition printed version + Flash disk with full paper version. ISBN 978-80-271-0248-8.

[10] Schneiderová Heralová, R. Life Cycle Costing Within Infrastructure Projects. In: Central Europe towards Sustainable Building 2016 - Innovations for Sustainable Future. Praha: GRADA PUBLISHING, 2016. pp. 1468-1475. 1st edition, Prague, June 2016, Complete edition - printed version + Flash disk with full paper version. ISBN 978-80-271-0248-8.

[11] Schneiderová Heralová, R. Highway Projects: Prices in Public Bids. Procedia Engineering. 2015, 2015(123), 496-503. ISSN 1877-7058. https://doi.org/10.1016/j.proeng.2015.10.101

[12] Dlask, P.; Beran, V. Long-Term Infrastructure Investment: A New Approach to the Economics Location. E+M Ekonomie a Management. 2016, 19(3), 40-56. ISSN 1212-3609.

[13] Franková, M. Scope of BIM Implementation in the Investment Phase of a Construction. In: Central Europe towards Sustainable Building 2016 - Innovations for Sustainable Future. Praha: GRADA PUBLISHING, 2016. pp. 741-748. 1st edition, Prague, June 2016, Complete edition - printed version + Flash disk with full paper version. ISBN 978-80-271-0248-8.

[14] Matějka, P.; Tomek, A. The Impact of BIM on Risk Management as an Argument for Its Implementation in a Construction Company. Procedia Engineering. 2014, 85 501-509. ISSN 1877-7058. https://doi.org/10.1016/j.proeng.2014.10.577

[15] All things BIM. Life cycle model of BIM. Available online at: http://www.allthingsbim.com/2010/03/nycbim-event-march-2010.html (accessed 20 Jan 2016).

[16] Matějka, P.; Kosina, V.; Berka, V.; Tomek, A.; Tomek, R.; Šulc, D. The Integration of BIM in Later Project Life Cycle Phases in Unprepared Environment from FM Perspective. In: Procedia Engineering. Amsterdam: Elsevier B.V., 2016. pp. 550-557. vol. 164. ISSN 1877-7058. https://doi.org/10.1016/j.proeng.2016.11.657

[17] Schneiderová Heralová, R. Life Cycle Costing Within Infrastructure Projects. In: Central Europe towards Sustainable Building 2016 - Innovations for Sustainable Future. Praha: GRADA PUBLISHING, 2016. pp. 1468-1475. 1st edition, Prague, June 2016, Complete edition - printed version + Flash disk with full paper version. ISBN 978-80-271-0248-8.

[18] Division4triclinium. MacLearny curve. Available online at: http://division4triclinium.blogspot.cz/2013/06/of-macleamy-curve-efficient-design-and.html (accessed 20 Jan 2016). 